\title{
Needs-oriented approach for decision support of industrial wastewater management
}

\author{
S. Grazilhon ${ }^{1}$, E. Piatyszek ${ }^{1}$, R. Hausler ${ }^{2}$ \& V. Laforest ${ }^{1}$ \\ ${ }^{I}$ Fayol Institute, Ecole Nationale Supérieure des Mines of Saint-Etienne \\ Graduate School of Engineering, France \\ ${ }^{2}$ STEPPE Laboratory, Ecole de Technologie Supérieure of Montréal \\ Graduate School of Engineering, Canada
}

\begin{abstract}
Historically, wastewaters are mostly discharged in rivers and more recently in wastewater treatment plants. These last few years the paradigm shift toward industrial ecology brought up the necessity of matching natural and anthropogenic cycles and so raised the interest for reuse of wastewater as raw material. Thereby, wastewater, depending on its characteristics, can be discharged to different types of receiving media - natural environment (river), urban wastewater treatment plants (WWTP), internal or external industrial units - after being properly processed. Thereby, the characteristics of the discharged water must meet the regulatory requirements. In Europe, two directives deal with this question. The first one, the Industrial Emission Directive (IED) is based on four principles: the integrative pollution prevention, the use of Best Available Techniques (BAT), flexibility, public participation and information access. The second one, the Water Framework Directive (WFD), gives general objectives for maintaining and restoring the European water bodies' quality. The application at the industrial level remains variable. In this context, we explored the possibility of considering the wastewater as a product, via a quality approach, linking the two European directives in an industrial ecology strategy. The thought process questions the possibility to transpose the principles and steps of quality management described in the ISO 9000 norm to industrial wastewater management. One key point of the transposition is the evaluation of the "client's" needs, which is quite easy when the receiving media is an industrial unit, becomes more difficult when it is a WWTP and even more in the case of a river.
\end{abstract}

Keywords: industrial wastewater, environment, quality, needs. 


\section{Introduction}

The emergence of sustainable development has resulted in the raise of integrated approaches of environmental issues. The environmental regulation in Europe is important (Industrial Emissions Directive, European Water Framework...) and could allow reaching sustainable development requirements. This led to new concepts and paradigms like industrial ecology. This new vision of the man to nature relationship brought us to consider people and activities in a general ecology context, aiming at matching natural and anthropogenic cycles.

This paper presents the first part of a research project that aims at proposing a decision support tool for the choice of industrial wastewater treatment techniques. The final objective of the project is to develop an innovative method in keeping with the implementation of the industrial emission directive (IED), the principles of the water framework directive (WFD) as well as the undertakings of a systemic analysis of the industry in its environment in order to be able to select an effluent treatment process according to its technical, economic, ecological and social aspects. Moreover, it must consider the specific features of the local environment in which the business operates, the specific character of the business and the effluents generated.

In this context, our approach is to wonder which place is devoted to the receiving environment in the decision making concerning the industrial effluent management. The finality is to adapt the industrial quality to the environmental quality concept in order to consider industrially generated effluent no more as a waste but as a product. Within this frame, a reflexion is proposed about this paradigm change, notably around the question of "needs" and "customers" inherent to the notion of quality.

\section{European regulatory frameworks}

Since the 1970s, the European Union (EU) has developed an environmental regulation. The Water Framework Directive 2000/60/EC [1] adopted in October 2000 by the European parliament sets a common water management policy for EU countries. The directive gives the following objectives:

- "prevents further deterioration and protects and enhances the status of aquatic ecosystems and, with regard to their water needs, terrestrial ecosystems and wetlands directly depending on the aquatic ecosystems;

- promotes sustainable water use based on a long-term protection of available water resources;

- aims at enhanced protection and improvement of the aquatic environment, inter alia, through specific measures for the progressive reduction of discharges, emissions and losses of priority substances and the cessation or phasing-out of discharges, emissions and losses of the priority hazardous substances; 
- $\quad$ ensures the progressive reduction of pollution of groundwater and prevents its further pollution, and

- contributes to mitigating the effects of floods and droughts."

In practice, EU countries have delimited national and international river basin districts, which are divided in water bodies equipped with monitoring stations. In application of the WFD, each country has to control and record all the wastewater discharges, the chemical and biological quality of all their water bodies and to settle quality improvement objectives for the coming years (the first deadline is 2015).

In the meantime, the Industrial Emission Directive [2, 3] and related documents provide guidelines and references to help industries controlling their environmental impact, such as Best Available Techniques (BAT) and associated emission levels, which are included in the BREF documents. This directive is built on four principles: integrative pollution prevention, Best Available Techniques (BAT), flexibility as well as public participation and information access. Concerning industrial wastewater, the treatment strategies have made a curative to integrative shift [3-7], including preventive practices. This new regulation makes mandatory the use of the BAT-Conclusions in the elaboration of a project concerned by the IED directive, although they are not available yet for all the sectorial BREFs.

The flexibility and BAT principles make of primary importance for EU countries to adapt these values to the characteristics of the local environment [6, 7] with the objective of a high level of environmental protection, notably in accordance with the WFD. Nevertheless, emissions should not be higher than the BAT Associated Emission Levels (BATAEL) provided by these documents [3, 8]. In the case of a discharge to the river, it must respect the quality objectives of the river, which means that concentrations in the river must not exceed the Environmental Quality Standards, established by the European directive 2008/105/CE [9], at its lowest flow. If the effluent is not released in the river, it is mainly directed to urban wastewater treatment plants. Then, the plant manager settles the threshold values, depending on the plant's capacity to treat the effluent. In this case too, very often, the limits adopted are those of the sectorial legislation.

The compliance of an industrial project with the objectives of these two directives (IED and WFD) must be established by the project manager in the Environmental Impact Assessment (EIA). This document must be provided to local authorities to obtain an operating permit. In particular, concerning effluent discharge the EIA has to demonstrate that the project reaches the performances of BAT (IED) and respects the quality objectives of the receiving environment (WFD).

\section{Limits of regulation}

Despite a comprehensive European regulation concerning industrial environmental impact management, the actors involved in the implementation of 
the two main European directives concerning this question are different and are not involved at the same levels of industrial permit delivery. It is to be pointed out that, in France, these actors do not possess the same amount of power in the negotiation process. For example, the only actor that legally decides the authorization conditions is the county prefect. All the others are only consulted in the process, which can sometimes lead to dissatisfaction of some of them or lack of environmental protection. This results in a difficult connection between the industrial (IED) and the environmental (WFD) directives. The implementation of the Water Framework Directive enabled to obtain data on the quality of the water bodies in Europe. In France, the measurement campaign completed in 2009 showed that only $45 \%$ of the water bodies have a good or very good ecological status and $45 \%$ have a good chemical status [10]. These figures underline the importance of the room for quality improvement of the European water bodies to reach the quality objectives for 2015 . For example in France, the European Commission esteemed in 2012 that only 5 to $20 \%$ of the water bodies could meet the WFD objectives [11].

Ecological status improvements, because of biological, morphologic and hydrological factors, can appear a certain amount of time after measures have been taken (ecological rehabilitation...). In a different way, the chemical status depends directly of the effective discharges in the media. Also, even if the problem of bad chemical status of water bodies can have many origins, the method recommended for the evaluation of a water body pollutant acceptance capacity [12] seems to show some limits. Indeed, the pollutant-carrying capacity of water bodies must be respected, which represents a concentration equivalent to Environmental Quality Standards (EQS) at low flow. The possible pollutant discharge load is the difference between the carrying capacity of the water body considered and the current pollutant load (mass flow) downstream of the discharge point, as shown in Figure 1:

$\mathrm{Q}_{\mathrm{WB}}=$ flow in the water body $\left(\mathrm{m}^{3} / \mathrm{d}\right)$

$\mathrm{C}_{\mathrm{WB}}=$ pollutant concentration in the water body $\left(\mathrm{kg} / \mathrm{m}^{3}\right)$

$\mathrm{Q}_{\mathrm{R}}=$ discharge flow $\left(\mathrm{m}^{3} / \mathrm{d}\right)$

$\mathrm{C}_{\mathrm{R}}=$ pollutant concentration in the discharge $\left(\mathrm{kg} / \mathrm{m}^{3}\right)$

EQS = Environmental Quality Standard of the considered pollutant

$\mathrm{Q}_{\text {low }}=$ lowest flow of the water body
Downstream of the discharge point

$\mathrm{Q}_{\mathrm{WB}}, \mathrm{C}_{\mathrm{WB}}$

Figure 1: Calculation of the discharge possibility in a water body for any pollutant.

Even if this method ensures that locally EQS are not exceeded, this approach raises several questions such as the action that should be taken, concerning industries willing to obtain a permit and/or already authorized industries, when 
the water body already reaches or exceeds its carrying capacity. Another problem is the information access, though the WFD constraints EU countries to collect and publish information concerning the water quality, the implementation of this principle remains unequal. For example, in France, for $34 \%$ of the water bodies, the chemical status is undetermined [10], which means that data are not available for the calculation of pollutant discharge possibility calculation.

These observations show the necessity at the territory level, to link human activities management with environmental impact management. This demarche is consistent with an industrial and territorial ecology (ITE) approach, where human activities are no more considered outside of natural ecosystems, but as a part of it, aiming at matching natural and anthropogenic cycles. Water, as a vital resource for every ecosystem, consumed for domestic, industrial and agricultural purposes and released into the environment is a relevant object of study in a comprehensive approach. Thereby, if humans are concerned by the quality of the water they consume, all the environmental regulations, the matter of sustainability and the new paradigms of environment-activities relationship (such as ITE) seem to lead, among others, to the question of our liquid discharge quality.

\section{Quality approach}

The term of quality used for environmental aspects appears in two categories:

- The products environmental quality which correspond to the environmental impact performances of this product;

- The quality of the environment, used for example in the European regulation (Water bodies' quality, Environmental quality standards...).

Yet, in an industrial ecology approach, where the symbiosis between the anthropogenic and natural cycles is pursued, we explore the possibility to study human and natural ecosystems at the same level and propose the possibility of considering industrial wastewater's quality as a product.

Appearing during the 17th century and widely developed in the 1970s for products and services, the notion of quality is based on the customer's satisfaction. In 1987, the ISO 9000 family of standards appears due to the following observation [13]:

"Customers require products with characteristics that satisfy their needs and expectations. These needs and expectations are expressed in product specifications and collectively referred to as customer requirements. Customer requirements may be specified contractually by the customer or may be determined by the organization itself. In either case, the customer ultimately determines the acceptability of the product. Because customer needs and expectations are changing, and because of competitive pressures and technical advances, organizations are driven to improve continually their products and processes.

The quality management system approach encourages organizations to analyze customer requirements, define the processes that contribute to the 
achievement of a product which is acceptable to the customer, and keep these processes under control."

The worldwide spread of this theory makes the ISO 9000 one of the main international frame for quality management.

In the ISO $9000-2005$, quality is defined as the "degree to which a set of inherent characteristics fulfills requirements" [13]. Thereby, the industrial quality management defined by the ISO 9000 is based on eight principles: customer focused organization, leadership, involvement of people, process approach, system approach to management, continual improvement, factual approach to decision making, mutually beneficial supplier relationships. Also this demarche seems appropriate to be transposed to effluent management, with a process approach.

The principles of product quality management are achieved through several steps [13] presented in Table 1. The idea explored in the research project is to transpose this approach and these principles to industrial effluent management by considering the effluent as a product.

In Table 1, an adaptation of these principles to industrial effluent management is proposed:

For most of the items (Table 1), the implementation does not appear to raise significant difficulties. However, those that seem to be less obvious in the application are the step a) concerning the question of the evaluation of the customers' needs and the transposition of these needs into process specifications and the step e), where indicators of compliance between the effluent discharged and the customers' needs could be necessary. Then, the focus will be made here on the first question raised by this transposition: the determination of the needs and expectations of customers and other interested parties (Item a), Table 1).

\section{Customers, interested parties and their needs}

If the industrial effluent is considered as a product, the customer is the receiver of this effluent. Thereby, there are different types of potential customers in the case of the transposition of product quality management to effluent quality management. The three different types are:

- Industrial units,

- Wastewater treatment plants,

- Natural environment (mainly rivers).

Defining the needs and expectations of the customer is the first step but not the least of a quality process. Generally speaking, the needs of an industrial unit are the raw material and energy necessary to elaborate a product. Wastewater treatment plants need wastewater that can be treated by the facilities. Then, in a first approximation, the need of a natural river lies in the necessary quality of the water for the ecosystem homeostasis [14]. Also, the wastewater discharged should be compatible with this constraint. This question will be developed further in the paper. 
Table 1: $\quad$ Proposition of an application of the quality management principles to industrial effluent management.

\begin{tabular}{|c|c|c|}
\hline & $\begin{array}{l}\text { ciple of product quality } \\
\text { agement (Source: ISO } 9000 \text { - } \\
\text { ) }\end{array}$ & $\begin{array}{l}\text { Declination and application for } \\
\text { industrial effluent management }\end{array}$ \\
\hline & $\begin{array}{l}\text { Determining the needs and } \\
\text { expectations of customers and } \\
\text { other interested parties }\end{array}$ & $\begin{array}{l}\text { Identification of the customers } \\
\text { and the interested parties, } \\
\text { - Identification and evaluation of } \\
\text { their needs }\end{array}$ \\
\hline & $\begin{array}{l}\text { Establishing the quality policy } \\
\text { and quality objectives of the } \\
\text { organization }\end{array}$ & $\begin{array}{l}\text { Considering the needs determined in } \\
\text { the a) step, the organization defines } \\
\text { the quality objectives of its effluent } \\
\text { (physical and technical } \\
\text { characteristics) }\end{array}$ \\
\hline & $\begin{array}{l}\text { Determining the processes and } \\
\text { responsibilities necessary to } \\
\text { attain the quality objectives }\end{array}$ & $\begin{array}{l}\text { The organization determines the } \\
\text { possible treatment processes that can } \\
\text { meet the effluent quality objectives } \\
\text { (this task can be subcontracted) and } \\
\text { selects the best according to the BAT } \\
\text { principles }\end{array}$ \\
\hline d) & $\begin{array}{l}\text { Determining and providing the } \\
\text { resources necessary to attain } \\
\text { the quality objectives }\end{array}$ & $\begin{array}{l}\text { Definition by the project manager of } \\
\text { the possible technical, economical, } \\
\text { software, human... resources }\end{array}$ \\
\hline e) & $\begin{array}{l}\text { Establishing methods to } \\
\text { measure the effectiveness and } \\
\text { efficiency of each process }\end{array}$ & $\begin{array}{l}\text { Definition of efficiency (eco- } \\
\text { efficiency) indicators }\end{array}$ \\
\hline f) & $\begin{array}{l}\text { Applying these measures to } \\
\text { determine the effectiveness and } \\
\text { efficiency of each process }\end{array}$ & $\begin{array}{l}\text { Settlement of a quality control } \\
\text { protocol that determines the } \\
\text { parameters that must be controlled, } \\
\text { how and how often }\end{array}$ \\
\hline & $\begin{array}{l}\text { Determining means of } \\
\text { preventing nonconformities and } \\
\text { eliminating their causes }\end{array}$ & $\begin{array}{l}\text { Wastewater flow mapping, data } \\
\text { processing, operating experience, use } \\
\text { of risk analysis methods (alarms, } \\
\text { cause trees) for identification and } \\
\text { prevention of potential non } \\
\text { conformities }\end{array}$ \\
\hline & $\begin{array}{l}\text { Establishing and applying a } \\
\text { process for continual } \\
\text { improvement of the quality } \\
\text { management system }\end{array}$ & \\
\hline
\end{tabular}

With this way of thinking liquid effluent quality, the finality of the wastewater treatment processes changes from depollution to resource production unit, which is also the case for a WWTP which joins the industrial unit category. The different possible product-customer scenarios are mapped in Figure 2. 


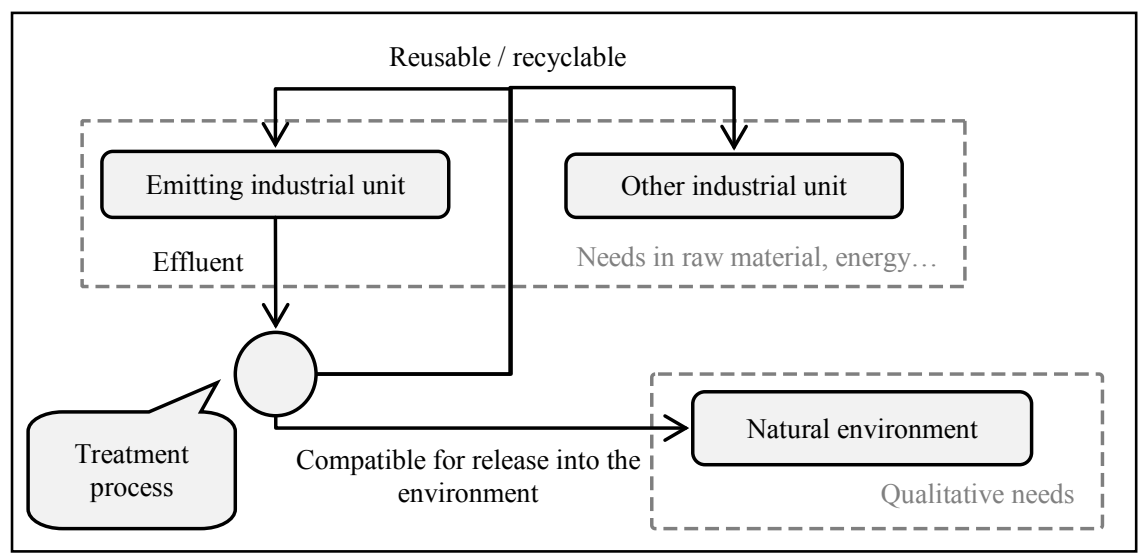

Figure 2: $\quad$ Product to customer mapped scenarios.

Depending on the countries, the interested parties are different. In France, the identified actors that interfere into industrial authorization procedures are organized according to the European and local legislation in different types:

- The project manager,

- Local actors that represent the government at the region, county, and municipality scale,

- Specialized public administrations,

- Environmental associations,

- Citizens.

The main needs identified for the interested parties are presented in Table 2.

Table 2: $\quad$ Main needs of the interested parties.

\begin{tabular}{|l|l|}
\hline Type of interested parties & Main needs \\
\hline Project manager & $\begin{array}{l}\text { Durability of the activity related to } \\
\text { regulation compliance, economic wealth, } \\
\text { etc. }\end{array}$ \\
\hline $\begin{array}{l}\text { Governmental local actors and } \\
\text { specialized public administration }\end{array}$ & $\begin{array}{l}\text { Compliance of the project with the } \\
\text { regulation (in Europe: the IED and the } \\
\text { WFD) }\end{array}$ \\
\hline Environmental associations & $\begin{array}{l}\text { Integrative and efficient environmental } \\
\text { protection, local actors participation }\end{array}$ \\
\hline Citizens & Well being \\
\hline
\end{tabular}

This means that the global thought process of industrial effluent treatment process must understand and take into account the needs of all these actors. These needs can be defined "contractually" like those that ensure the compatibility of the project with the national and European regulation. They can also be very specific, depending on the local characteristics of the territory. 
Once the different needs and expectations of the customers and interested parties are identified, they must be evaluated. When the customer is an industrial unit (including a wastewater treatment plant), the manager can provide specifications for the product (quantity, quality, temporal evolution...). Should the customer be a natural river, it will not be able to express its needs. The question is then: are we able to evaluate the needs of a natural ecosystem?

In Maslow's hierarchy of needs, the first are the physiological ones [15]. Transposed to any ecosystem, this notion can be encompassed in the term of homeostasis, which represents its multiple dynamic equilibrium and regulation mechanisms [16]. These mechanisms, for natural ecosystems, have been research objects for a long time. As a result, river ecosystem models are currently available [17-20]. However, they take into account a limited number of parameters and equations which means that they contain empirical parameters and need specific calibrations, which involve a huge amount of data, which are not always available. Moreover, these complex simulation tools are not adapted to unspecialized users, which make them not suitable for industrial decision support.

To conclude, in the case of an industrial unit (incl. WWTP) at the customer position, the evaluation of the needs can be done by the manager and specified in a contract. This is not the case when the customer is a natural ecosystem, which means that it cannot be considered this way in accordance to the ISO 9000 quality principles.

\section{New paradigm and perspectives}

As the customer concept is not transposable for natural ecosystems, the approach chosen is then to consider human needs in relation with the ecosystems. The reasons for this choice are twofold:

- Humans are part of the global natural ecosystem and depends entirely on it;

- Human needs encompass the needs of all the interested parties and can be expressed.

Indeed, human society depends on the environment for resources provisioning and waste detoxification but also for multiple services. The ecosystem services have been inventoried within the frame of the Millennium Ecosystem Assessment launched by the United Nations in 2001. The objective was then to measure the consequences of ecosystems modifications on populations' wellbeing and poverty on a global scale. Also, the ecosystem services are divided in four categories according to many authors [21]:

- Support services (Habitat, soil formation, photosynthesis...);

- Provisioning services (Freshwater, energy, food, timber, biochemical/medicine...);

- Regulating services (global and local climate, air quality, water quality, pollination...);

- Cultural services (recreation and aesthetic value...). 
In this context, we propose to consider as an environmental aspect of the main product's quality, the needs of the human society concerning the services provided by the ecosystem which receives the industrial wastewater. This demarche includes the relationship between the activity and its environment and globalizes the quality management principles as shown in Figure 3:

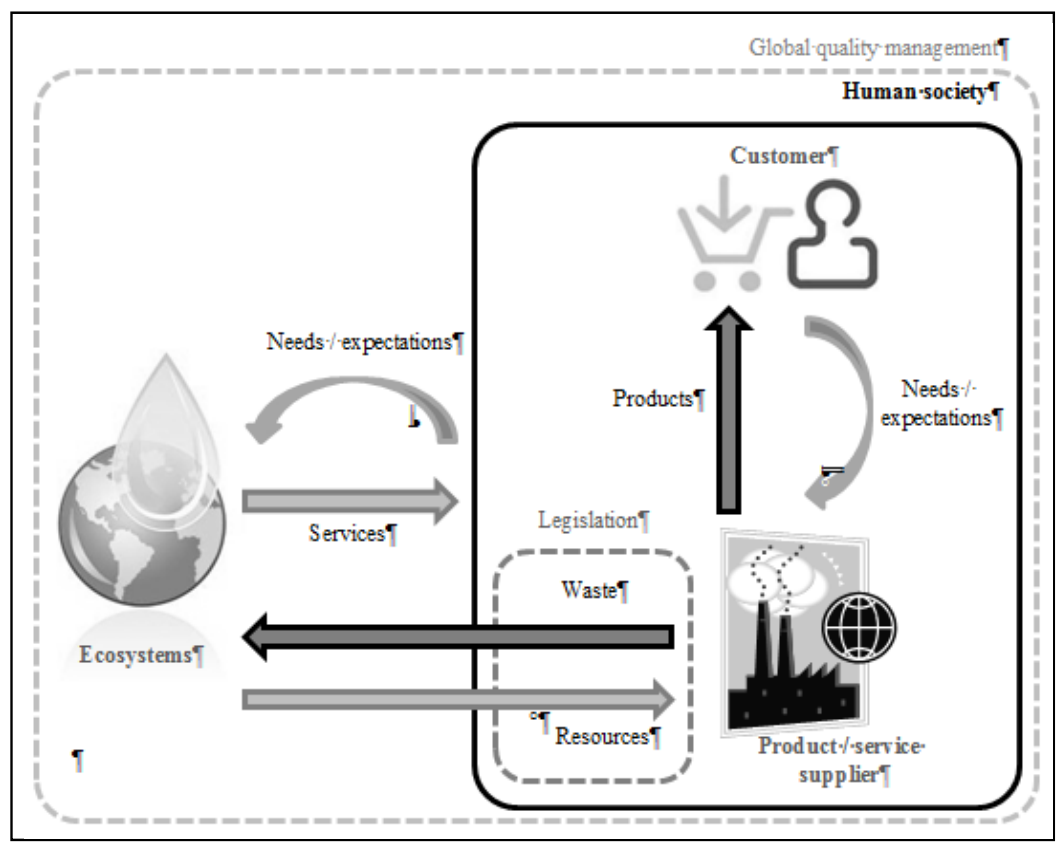

Figure 3: Proposition of a quality management thought process that replaces the activity in relation with the natural ecosystems.

Also, with this method, we do not consider the needs of the environment but those related to it, that is to say the needs of the society concerning the ecosystems. In practice, the application of the item a) of the Table 1 could lead to a local study of the environment, in order to identify:

- The potential services provided by the type of the identified ecosystem,

- The effective ability of this ecosystem to provide these services,

- The possibility for these services to be affected by wastewater discharges, and

- The potential targets that could be affected by a decrease of the ecosystem's ability to provide these services.

This demarche is inspired by the tools and methodologies proposed by the World Resource Institute [22] in order to use the ecosystem services for environmental impact assessments. This approach is quite similar with the risk analysis method "source-pathway-target" chain. 
Nevertheless, the aim of the step a) of the Table 1 is to provide quantitative data related to the needs in order to complete the following steps. Particularly, these data must be used to elaborate and operate the production process (steps c) and d) of the Table 1). Although, even if some authors provide global indicators for the ecosystem services [21], they remain difficult to quantify especially for a decision support purpose which requires easily available data.

\section{Conclusion}

Industrial wastewater management in Europe is submitted to two main directives. The first one promotes the use of Best Available Techniques and integrated pollution prevention. The second one concerns natural water bodies' quality management. Industrials are supposed to refer to these two directives in the elaboration of their projects, which should appear in their Environmental Impact Assessment. However, it appears that a more territorial approach could be beneficial. Thereby, we propose an adaptation of the ISO 9000 quality management international standard to wastewater's quality management. The main problem raised by this approach is the evaluation of the customer's needs in the case of a discharge in natural ecosystems, while the transposition is quite easy when the customer is an industrial unit or a wastewater treatment plant. Taking into account the needs of the human society related to the environment allows bypassing the problem of the ecosystem-customer which needs cannot be expressed. Actually, quantifying these needs in order to support industrial decision making will be the next step of the research project.

\section{References}

[1] European Parliament and Council, 2000, Directive 2000/60/CE of the European Parliament and of the Council of 23 October 2000 establishing a framework for community action in the field of water policy.

[2] European Parliament and Council, 2010, Directive 2010/75/UE of the European Parliament and of the Council of 24 November 2010 on industrial emissions (integrated pollution prevention and control) (recast).

[3] A. Cikankowitz, V. Laforest, Using BAT performance as an evaluation method of techniques, Journal of Cleaner Production, Volume 42, March 2013, Pages 141-158.

[4] V. Laforest, R. Berthéas Ambiguïté entre technologies propres et meilleures techniques disponibles, VertigO, Vol6, n², 2005.

[5] Cikankowitz A, (2008) Méthodologie d'évaluation des performances environnementales des techniques en vue de les comparer puis de les valider "meilleures techniques disponibles", these de doctorat, ENSM.SE, $379 \mathrm{p}$.

[6] V. Laforest, Applying Best Available Technologies in environmental management accounting? From the definition to an assessment methodology, pp29 à 48, 5ème EMAN book "Environmental Management 
Accounting for Cleaner Production”, EMAN, Springer, 2008, ISBN : 9781-4020-8912-1, 500p dirigé par Stefan Schaltegger.

[7] Cikankowitz, A., Raymond, G., Piatyszek, E. \& Laforest, V. 2009, "Evaluation et intégration de la sensibilité intrinsèque des milieux récepteurs dans une méthodologie d'évaluation des performances environnementales", Revue Francophone d'Ecologie Industrielle, vol. 55, pp. 27-35.

[8] Rajaram, T. \& Das, A. 2008, "Water pollution by industrial effluents in India: Discharge scenarios and case for participatory ecosystem specific local regulation", Futures, vol. 40, no. 1, pp. 56-69.

[9] European Parliament and Council, 2008, Directive 2008/105/EC of the European Parliament and of the Council of 16 December 2008 on environmental quality standards in the field of water policy.

[10] Eaufrance, République Française, 2010, La reconquête du bon état des eaux et des milieux aquatiques- De l'état des eaux en 2009 aux objectifs de 2015.

[11] European Commission, 2007, Surface water bodies not at risk (map).

[12] Ministère de l'aménagement du territoire et de l'environnement, 2001, L'étude d'impact sur l'environnement.

[13] AFNOR, 2005, NF EN ISO 9000, Quality management systemsfundamentals and vocabulary.

[14] Grazilhon, S., Piatyszek, E., Laforest, V., \& Hausler, R. (2012). Méthodologie d'aide à la décision pour la qualité globale des effluents et la protection du milieu récepteur. In Actes du Colloque Interdisciplinaire sur l'Ecologie Industrielle et Territoriale (COLLEIT).

[15] Poston, B. (2009). Maslow's Hierarchy of Needs. Surgical technologist, 348.

[16] Claude Bernard, Introduction à l'étude de la médecine expérimentale, 1865.

[17] Vagnetti, R., Miana, P., Fabris, M., \& Pavoni, B. (2003). Self-purification ability of a resurgence stream. Chemosphere, 52(10), 1781-1795.

[18] Tian, S., Wang, Z., \& Shang, H. (2011). Study on the Self-purification of Juma River. Procedia Environmental Sciences, 11, 1328-1333.

[19] Cukrov, N., Cmuk, P., Mlakar, M., \& Omanović, D. (2008). Spatial distribution of trace metals in the Krka River, Croatia: an example of the self-purification. Chemosphere, 72(10), 1559-1566.

[20] Gomez, E., Ledoux, E., Viennot, P., Mignolet, C., Benoit, M., Bornerand, C., ... \& Brunstein, D. (2003). Un outil de modélisation intégrée du transfert des nitrates sur un système hydrologique: application au bassin de la Seine. La Houille Blanche, (3), 38-45.

[21] Burkhard, B., Kroll, F., Müller, F., \& Windhorst, W. (2009). Landscapes' capacities to provide ecosystem services-a concept for land-cover based assessments. Landscape online, 15, 1-22.

[22] World Resources Institute, 2011, Ecosystem Services Review for Impact Assessment - Introduction and Guide to Scoping. 